\title{
Soils and soil ecology in Khorezm
}

Akmal Akramkhanov ${ }^{1}$, Ramazan Kuziev ${ }^{2}$, Rolf Sommer ${ }^{3}$, Christopher Martius ${ }^{4}$, Oksana Forkutsa $^{1}$, Luiz Massucati ${ }^{5}$

${ }^{1}$ Center for Development Research (ZEF), Walter-Flex-Straße 3, 53113 Bonn, Germany

${ }^{2}$ State Scientific Research Institute for Soil Science and Agrochemistry, Kamarniso 3, 700179 Tashkent, Uzbekistan

${ }^{3}$ International Center for Agricultural Research in the Dry Areas (ICARDA), P.O. Box 5466, Aleppo, Syrian Arab Republic

${ }^{4}$ Inter-American Institute for Global Change Research, Av. dos Astronautas, 1758 12227-010 - São José dos Campos, SP, Brazil

${ }^{5}$ Institute of Organic Agriculture, University of Bonn, Katzenburgweg 3, 53115 Bonn, Germany

\section{Abstract}

The current status of the agricultural soils in Khorezm is closely linked to their development influenced by past river flows and more recent human-managed irrigation and drainage practices. The initial relief of the Amu Darya river delta was formed by ancient channels that carried large amounts of sediments. When irrigation was introduced, sediments started to be deposited on croplands, a process which formed the now spatially distinct features in the topsoils. Today's landscape of the ancient river delta is thus significantly influenced by human interference. The areas presently used for irrigated agriculture are traversed by a network of irrigation canals, collectors and drains. Longterm irrigation formed a layer of uniform topsoil, referred to as an agro-irrigation horizon, covering a multi-layered alluvium. This chapter provides an impression of the current state of land resources in the irrigated areas of the Khorezm region. We analyzed soil properties based on present and past data; the latter from a period before agriculture expanded and intensified. Soil texture is dominated by silt loam layers together with sandy loams and loams that constitute almost $80 \%$ of all soil layers. Organic matter in irrigated soils is low, constituting on average $7.5 \mathrm{~g} \mathrm{~kg}^{-1}(0.75 \%)$ in the topsoil layers and decreasing in the deeper layers. Afforestation can increase SOC stocks. Soil microbiological activities reflected in the soil respiration rate were closely linked to soil 
organic carbon content and revealed considerable carbon accumulation under zero-tillage systems. Soil macrofauna density was highest under vegetation dominated by one tree species, Euphrates poplar (Populus euphratica Oliv.; Salicaceae), but its biodiversity was highest in cultivated sites (and dominated by small predatory arthropods). These results may serve as benchmarks in future monitoring of land use effects on soil quality. Most subsoils in Khorezm are slightly- to medium-saline, whereas the majority of topsoils above $60 \mathrm{~cm}$ are strongly saline. Between 1960 and 1990, moderately saline soils increased from $21 \%$ to $31 \%$, and highly saline soils, from $6 \%$ to $21 \%$.

Key words: landscape, salinity, soil respiration, micro- and macro-fauna, texture

\section{Soils evolution and land resources}

The development of soils in Khorezm has, over the millennia, been greatly and primarily influenced by water from a meandering Amu Darya river. It therefore is relevant to understand the processes responsible for the spatial distribution of the different soil types. Central Asian oases, isolated areas of vegetation surrounded by deserts, are among the few regions in the world where irrigation resulted in the development of new anthropogenic soils overlaying the natural formations. Therefore, in particularly the upper layers of soils in the Khorezm region are relatively new formations compared to those soils that developed under natural conditions without human interference.

Irrigated agriculture in Khorezm has a long history (Tolstov 1948, Tsvetsinskaya et al. 2002). Soil evolution has been considerably faster under irrigation than in natural systems, and significant changes in soil properties can occur even within 10 to 100 years. Furthermore, intensive soil displacements occurred when the irrigation and drainage system was developed. Lithology, geomorphology, hydrochemistry and other local peculiarities such as the very flat terrain provide the background against which this intensive human interference has altered soil formation processes, including the mineralisation of soil organic matter and microbiological activity, salt migration, illuviation and clay formation.

Features produced by water flows such as the riverbed, near-bed formations, and depressions can be distinguished and are described in detail by Felitciant (1964) and Tursunov (1981). The latter author explains that the initial relief of the Amu Darya river 
delta in Khorezm was formed by two ancient channels, the so-called Daryalyk and Daudan. These transported large amounts of soil sediments, which were deposited and formed levees. Near-bed levees usually contain coarse-grained material, i.e. sand and silt. However, occasionally these are covered by finer grain material deposited during lowvelocity floods. Areas further away from the riverbeds are characterised by layers of fine material that was deposited from suspended loads in slow-flowing waters, or even indicating areas of previously stagnant water that formed loamy and clayey soils. Also, since streams were constantly changing courses and braided the delta region, the vertical and lateral composition of the soils is very varied (Tursunov 1981).

Another factor that affected soil formation during the floodplain-alluvial periods consists in the marshy and meadow-marshy formations on flat areas between intra-bed depressions, which were covered by reeds and often flooded. The interaction of vegetation and floods formed the meadow soils, characterized by groundwater tables deeper than 3 meters and a high organic matter accumulation on the surface. Elevated relief areas such as slopes and levees were also under meadow and meadow-marshy soil formation, but occasionally also transformed into solonchaks. These latter soils have developed mainly under a cover of grass vegetation and with a shallower groundwater table varying between 0.5-2.0 m (Kuziev 2006).

Large near-bed levees covered by bush and grass vegetation and experiencing groundwater table depths between 1-2.5 m formed meadow Tugai soils which morphologically resemble the features of the soils under Tugai forests (natural floodplain forests along the Amu Darya, cf. Khamzina et al., this book). These soils received litter inputs from the vegetation, explaining why soil organic matter contents often surpass $3 \%$.

Today's landscape in Khorezm, however, is significantly altered by human interference. Owing to the intensification of irrigated agriculture over the last 100 years or so, the areas converted into cropland have been traversed by a network of irrigation and drainage canals. Long-term, intensive irrigation formed a layer of uniform topsoil, referred to as the agro-irrigation horizon, which now covers the multi-layered alluvium deposits. Even ridged-hummocky sands, often present in the region, have been levelled and converted into farming land. A large part of the natural Khorezm landscape was transformed into cultured land.

Hydrogeology is another driver of soil formation. The initial hydrogeological conditions disfavored an intensive and widespread irrigated agriculture in Khorezm due to the flat 
topography, which limits lateral groundwater flow and results in shallow groundwater tables and increased soil salinity, despite the constructed collector-drainage network (cf. Tischbein et al., this book) The regular occurrence of high groundwater tables, then, in turn, created hydromorphic conditions favorable to solonchak formation. The elevated groundwater table enhances vertical water movement, and considerable amounts of water is discharged via evaporation and transpiration rather than via the drainage system, leading to soil and groundwater salinization. According to soil surveys conducted by the State Scientific Research Institute for Soil Science and Agrochemistry (SSRISSA) in 1996 (Kuziev 2006, Ibrakhimov et al. 2007), around 73\% of the territory of Khorezm had groundwater tables at 1-2 m.

Khorezm occupies an area of 646400 ha (GKZGK 2009), which includes a large desert area on the right bank of the Amu Darya, which is often excluded from assessments of land resources; the irrigated areas cover only about 276000 ha, the largest share of which is occupied by cropland (Table 1).

Table 1: Land resources of Khorezm, 1'000 ha (GKZGK 2009)

\begin{tabular}{|l|l|l|l|c|l|l|l|l|l|}
\hline \multirow{2}{*}{} & \multicolumn{4}{|c|}{ Agricultural land } & \multirow{2}{*}{ Household } & Forest & Garden & Other & TOTAL \\
\cline { 2 - 9 } & Cropland & Trees & Marginal & Pasture & & & & & \\
\hline Irrigated & 208.6 & 13.6 & 4.5 & 6.4 & 43.0 & 0.4 & 0.1 & & 276.6 \\
\hline Total & 208.6 & 13.6 & 4.5 & 141.2 & 51.0 & 57.5 & 0.1 & 169.9 & 646.4 \\
\hline
\end{tabular}

The following definitions (GKZGK 2009) apply to the categories in Table 1. Marginal lands include irrigated and rainfed areas that are out of production due to the deteriorated soil quality and irrigation management caused by inefficient use; or affected by erosion, strong salinization, gypsum, and poor land development. In the irrigated region, marginal lands are located in small patches at the border of cropped areas, and, provided that irrigation and drainage measures are implemented, these could eventually be recovered and used in agriculture (GKZGK 2009). Areas under trees are mainly fruit and mulberry plantings, and vineyards (cf. Khamzina et al., this book). The household area can include buildings and kitchen garden plots (cf. Bobojonov et al., this book).

The total irrigated area in 2009 was 1.5 times higher than that reported 30 years ago by SSRISSA (Kuziev 2006). More than $95 \%$ of the irrigated areas are meadow soils, whilst about $4 \%$ are marshy-meadow soils. Meadow soils, developed on alluvial deposits, are 
considered to be the most fertile land resources and have therefore been brought into cultivation. Soils developed on illuvium are considered less suitable for farming, explaining why only a fraction of these soils is currently cultivated (Kuziev 2006).

Soil quality conditions in Uzbekistan are reflected in the so-called soil bonitet. Soil bonitet is a relative score, ranging from 0 to 100 , given to indicate the soil quality and natural fertility (GKZGK 2009). Bonitet is an aggregate of several parameters ranging from field characteristics (morphology, etc.) to results of laboratory analyses for various soil properties (fertility, chemistry, etc.). Since cotton is the major crop in irrigated agriculture of Uzbekistan, it is used as the reference crop in soil bonitet assessments (GKZGK 2009). Table 2 presents data on estimates of soil bonitet scores for the agricultural land resources of about 233000 ha which includes cropland, trees, marginal land, and pasture. The average soil bonitet of these land resources is 53.

Table 2: Soil bonitet and area size (ha) according to land cadastre groups and soil classes of the agricultural land resources in Khorezm based on an assessment in 2005 (GKZGK 2009)

\begin{tabular}{|l|l|l|l|l|l|l|l|l|l|l|}
\hline $\begin{array}{l}\text { Land } \\
\text { cadastre } \\
\text { group }\end{array}$ & \multicolumn{2}{|c|}{ Bad } & \multicolumn{2}{|c|}{ Below average } & \multicolumn{2}{c|}{ Average } & \multicolumn{2}{c|}{ Good } & \multicolumn{2}{c|}{ Very good } \\
\hline Soil class & I & II & III & IV & V & VI & VII & VIII & IX & X \\
\hline Bonitet & $0-10$ & $11-20$ & $21-30$ & $31-40$ & $41-50$ & $51-60$ & $61-70$ & $71-80$ & $81-90$ & $91-100$ \\
\hline Hectares & n.a. & 625 & 8839 & 46296 & 34932 & 82052 & 49291 & 11848 & 102 & n.a. \\
\hline
\end{tabular}

n.a. = not available

\section{Soil physical and chemical parameters}

The description of the physical and chemical parameters of soils in Khorezm, and the following classification are largely based on a comprehensive data base of soils in the region collected by SSRISSA (Abdunabi Bairov, personal communication) organized into the Khorezm Soil Data Base by the ZEF-UNESCO Khorezm Project and, in the case of soil organic matter, supported by a comprehensive literature study carried out by Kuziev (2006).

\section{Texture and soil horizons}

The Khorezm Soil Data Base contains 511 soil profiles and altogether 2157 soil layers. The Soviet Union system of defining textural fractions differs from the one adopted by 
FAO where fewer textural fractions are defined (Stolbovoi 2000). However, according to Stolbovoi (2000), who provides a correlation between the Soviet Union and FAO soil classification systems, these differences due to this partial incongruence of the classification systems are mostly irrelevant, and the generalised textural classes can be correlated adequately for practical purposes at a global scale (Table 3).

Table 3: Correlation of particle size distribution between FAO and Soviet Union systems for soil textural classification (Stolbovoi 2000)

\begin{tabular}{|c|c|c|c|}
\hline \multirow{2}{*}{\multicolumn{2}{|c|}{ Name of texture fraction }} & \multicolumn{2}{|l|}{ Particle size $(\mathrm{mm})$} \\
\hline & & \multirow{2}{*}{$\begin{array}{l}\text { FAO system (1988) } \\
\geq 2\end{array}$} & \multirow{2}{*}{$\begin{array}{l}\text { Soviet Union system (1967) } \\
\geq 1\end{array}$} \\
\hline \multicolumn{2}{|c|}{ Gravel, fine gravel } & & \\
\hline \multirow[t]{3}{*}{ Sand } & Coarse & & -0.5 \\
\hline & Medium & -0.06 & -0.25 \\
\hline & Fine & & -0.05 \\
\hline \multirow[t]{3}{*}{ Silt } & Coarse & & -0.01 \\
\hline & Medium & -0.002 & -0.005 \\
\hline & Fine & & -0.001 \\
\hline \multicolumn{2}{|l|}{ Clay } & $\leq 0.002$ & $\leq 0.001$ \\
\hline \multirow[t]{3}{*}{ General classes } & Coarse & -0.06 & 0.05 \\
\hline & Medium & -0.002 & -0.001 \\
\hline & Fine & $\leq 0.002$ & $\leq 0.001$ \\
\hline
\end{tabular}

Out of all profiles available in the Khorezm Soil Data Base, 1884 had a complete set of information, allowing the conversion of soil texture classes into the FAO system (according to a formula provided in Shein 2009). Figure 1a shows the spatial distribution of the soil profiles, indicating a thomogenous, representative sampling scheme. The available soil samples from the rayons Shavat and Pitnyak (south-east of Khazarasp and not shown in this map) were not geo-referenced. 

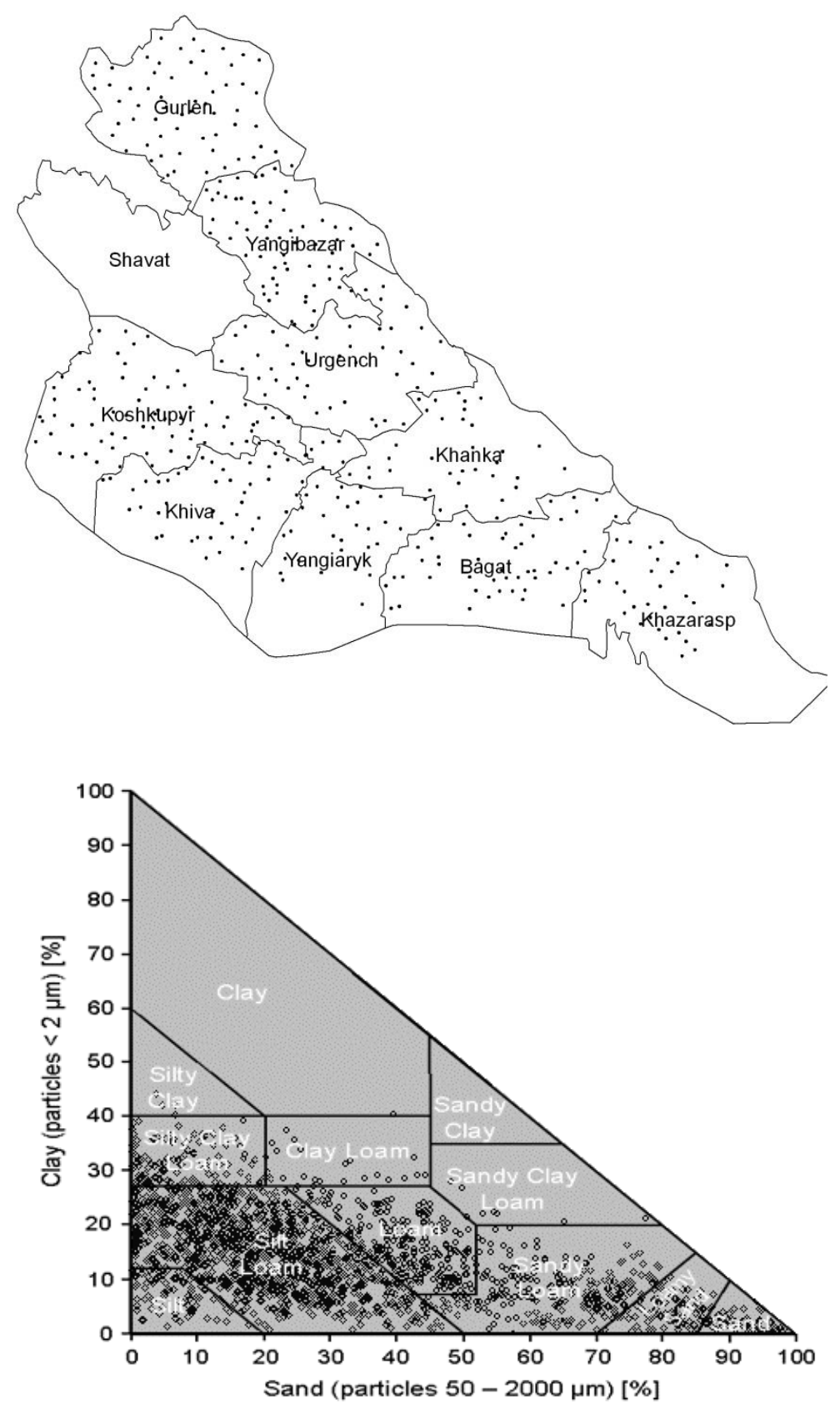

Figure 1: a) Approximate sampling locations of profiles, and b) USDA soil texture classification of these soil samples and respective distribution for all soil layers described in the Khorezm Soil Data Base (Sommer et al. 2010)

On average four generic soil horizons per profile are described in the database. For merely 35 soil profiles $(\sim 7 \%)$ more than 5 , at maximum 7 , horizons have been identified. Most soils in Khorezm are silt loams (USDA soil texture classification). Silt loam layers together with sandy loams and loams constitute almost $80 \%$ of all soil layers (Table 4). Clayey soils are hardly present in Khorezm (Figure 1b). Heavy textured soils are frequent at deeper layers (Figure 2). This means that the impact of shallow groundwater and groundwater salinity on crop growth and secondary soil salinization, respectively, is 
potentially significant, because heavier soils better support capillary rise of groundwater (Brouwer et al. 1985; cf. Tischbein et al., this book).

Table 4: Frequency of soil texture classes of the irrigated areas in Khorezm (Khorezm Soil Data Base, Abdunabi Bairov, personal communication), according to USDA soil classification

\begin{tabular}{lrr}
\hline Soil texture & N & \multicolumn{2}{c}{3.1} \\
\hline Sand & 59 & 86 \\
Loamy sand & 86 & 4.6 \\
Sandy loam & 229 & 12.2 \\
Clay loam & 25 & 1.3 \\
Loam & 241 & 12.8 \\
Sandy clay loam & 8 & 0.4 \\
Silt loam & 1039 & 55.1 \\
Silt & 84 & 4.5 \\
Silty clay loam & 109 & 5.8 \\
Silty clay & 3 & 0.2 \\
Clay & 1 & 0.1 \\
All & 1884 & \\
\hline
\end{tabular}

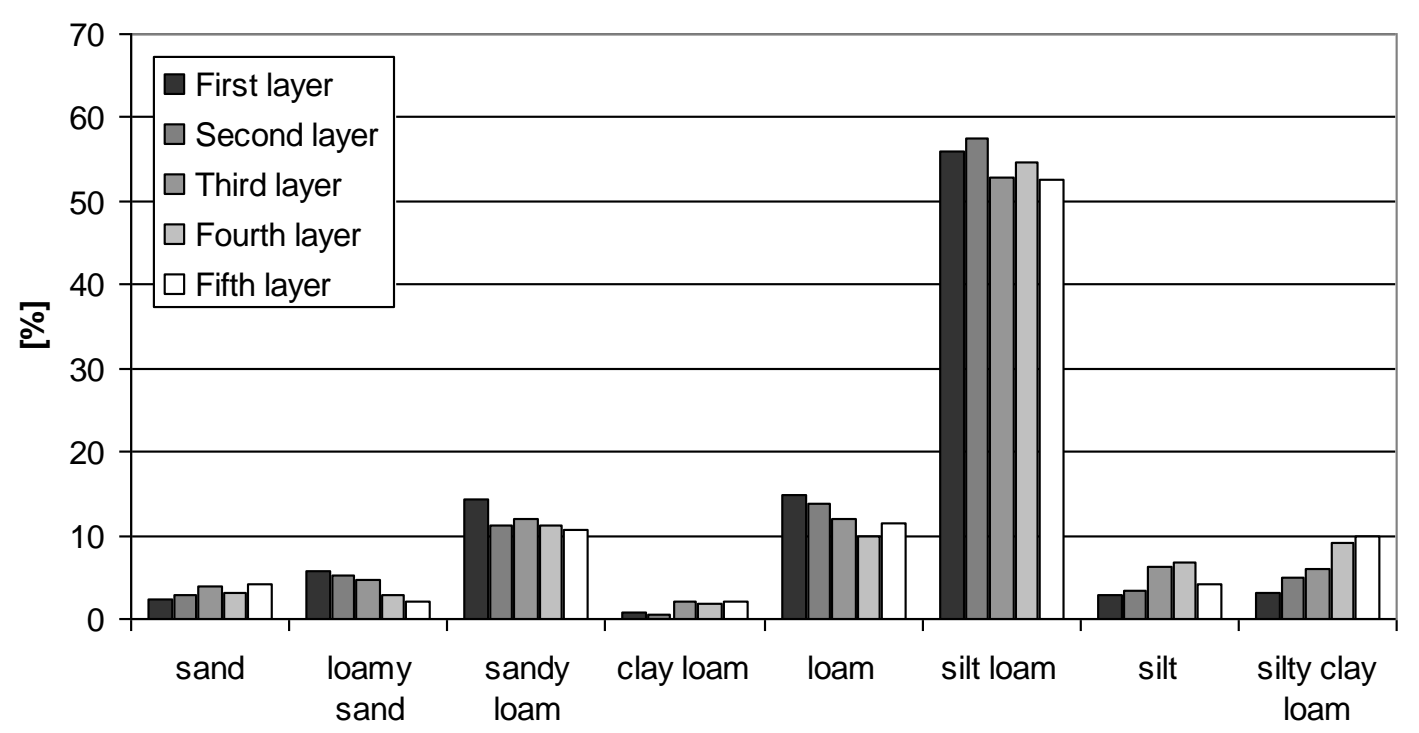

Figure 2: Frequency distribution of eight soil texture classes in the upper five soil layers in Khorezm

There is not much change along the soil profiles in the top $56 \mathrm{~cm}$; profiles are rather homogenous. For instance, altogether $55 \%$ of the soils have identical first and second soil 
layer textural classes. Furthermore, another $33 \%$ of all soil profiles had closely matching first and second soil layers (i.e. neighbouring soil textural classes in Figure 1). This indicates that only about $12 \%$ of all soil profiles show a rather abrupt texture change in the top $56 \mathrm{~cm}$ soil. Considering the first four soil layers, this percentage increased to $25 \%$, meaning that still $75 \%$ of the soils in the Khorezm Soil Data Base have a homogenous texture in the top $\sim 129 \mathrm{~cm}$. This is an important aspect, as it allows robust estimations of the vertical distribution of soil texture based only on topsoil data.

Soil parameters that highly correlate with clay content could be estimated with higher precision for monitoring purposes. The importance of monitoring the changes in agricultural land resources is acknowledged by the Government of Uzbekistan ${ }^{1}$, which has introduced guidelines to streamline monitoring of those resources throughout the country in three stages, namely, (1) preparatory works, (2) baseline field studies, and (3) long-term observations. By 2009, the second stage, baseline studies, was completed in most of the regions in Uzbekistan (GKZGK 2009).

\section{Soil organic matter}

The Khorezm soil database contains 1806 entries for soil organic matter (SOM). Soil organic carbon (SOC) in Uzbekistan is conventionally chemically determined, using a slightly modified form of the Walkley-Black wet-oxidation (potassium dichromate) method (Nelson and Sommers, 1982). For the conversion, it is assumed that SOM contains 58\% SOC (Vorobyova 1998).

SOM contents turned out to be low in the soils of Khorezm (Khorezm Soil Data Base). On average, SOM is $7.5 \mathrm{~g} \mathrm{~kg}^{-1}(0.75 \%)$ in the topsoil layers, decreasing to $3.9 \mathrm{~g} \mathrm{~kg}^{-1}$ at $156-210 \mathrm{~cm}$ depth, with considerable natural variation. The lower quartile of SOM at 0$32 \mathrm{~cm}$ was $5.4 \mathrm{~g} \mathrm{~kg}^{-1}$ and the upper quartile $9.4 \mathrm{~g} \mathrm{~kg}^{-1}$ (Figure 3).

SOM contents of the data set $(n=148)$ described by Kuziev (2006) generally concur with those of the Khorezm Soil Data Base. SOM content of heavy- and medium-textured irrigated soils varied from 6-7 to $11-14.5 \mathrm{~g} \mathrm{~kg}^{-1}$, gradually decreasing with depth. Light-

${ }^{1}$ Order No.496 of Cabinet of Ministers from 23.12.2000 on adoption of charter for agricultural lands monitoring 
textured soils contained 4.5-8.0 $\mathrm{g} \mathrm{kg}^{-1} \mathrm{SOM}$, but this decreased to $0.2-0.3 \mathrm{~g} \mathrm{~kg}^{-1}$ at deeper depth. The overall SOM storage of the $0-50 \mathrm{~cm}$ layer thus amounts to $16-79 \mathrm{t} \mathrm{ha}^{-1}$.

The subsoils of irrigated meadow soils are rich(er) in SOM as compared to the subsoils under natural formations where organic litter contributes to only topsoil (Kuziev 2006). Only due to irrigation, SOM can decrease from 12-20 $\mathrm{g} \mathrm{kg}^{-1}$ to $7-12 \mathrm{~g} \mathrm{~kg}^{-1}$ (Kuziev 2006).

The comparison of the data from 1950-1959 for the 0-30 and 30-50 cm layers with those from the 1970s and 1990ies demonstrates a general trend in SOM reduction (Figure 4). Meadow oasis soils located on ancient riverbeds and near-bed deposits had the highest SOM contents, followed by irrigated meadow soils. The lowest SOM content was found on meadow soils developed on recent Amu Darya deposits.

While irrigation water tends to wash out SOM, it is also one often neglected source of SOM (Kuziev 2006), and deposits suspended sediments rich in nitrogen, phosphorus, potassium, $\mathrm{OM}$ and a number of microelements. Irrigation water is a significant source of mineral replenishment of irrigated soils, particularly for automorphic soils of the desert zone, which are prone to enhanced SOM losses compared to soils with hydromorphic or semi-hydromorphic conditions. However, following the construction of the Tuyamuyun reservoir on the Amu Darya, located immediately upstream of Khorezm, most suspended solids in the river water are now being retained in this reservoir (Tashkuziev 2003).

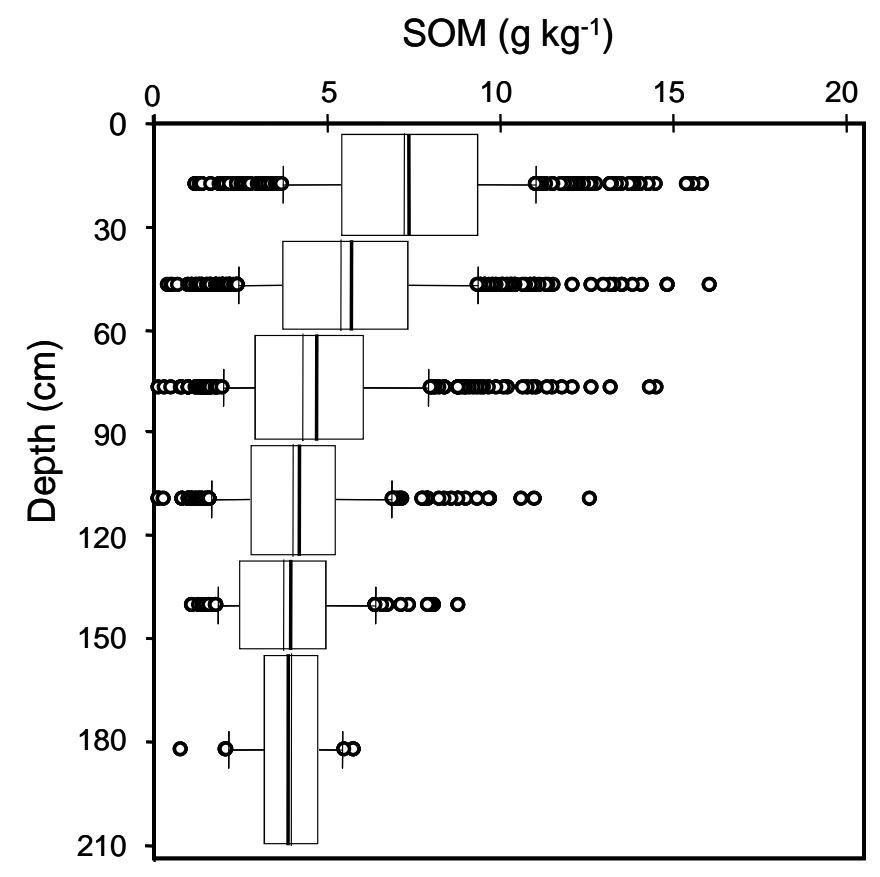

Figure 3: Soil organic matter of soils in the Khorezm soil database; box-whisker plots, bold lines within the box indicate average values, thin lines indicate median values. 


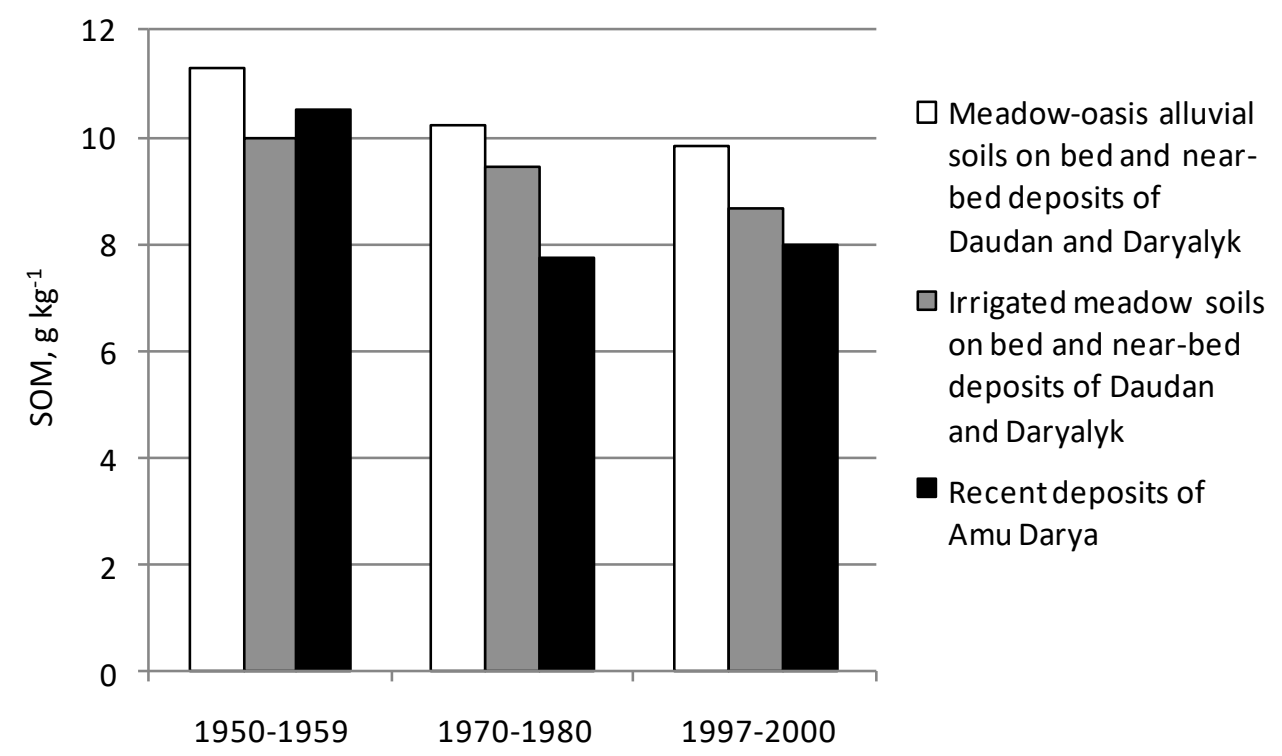

Figure 4: Comparison of soil organic matter content of irrigated topsoil $30 \mathrm{~cm}$ from 1950 to 2000 (adapted from Kuziev 2006)

\section{Soil NPK}

Due to the low SOM content in Khorezm soils, total soil nitrogen (N) levels are also low, ranging from $0.2-0.8 \mathrm{~g} \mathrm{~N} \mathrm{~kg}^{-1}(0.02-0.08 \%)$, with storage of $1.6-4.9 \mathrm{t} \mathrm{N} \mathrm{ha}^{-1}$ in the $0-50$ $\mathrm{cm}$ layers. The total $\mathrm{N}$ in irrigated soils reaches $4-6 \mathrm{t} \mathrm{ha}^{-1}$, out of which approximately $2 \mathrm{t}$ $\mathrm{ha}^{-1}$ are in the topsoil.

Total phosphorus (P) ranges from 450 to $3000 \mathrm{mg} \mathrm{P} \mathrm{kg}^{-1}$. Marshy-meadow soils have usually high (1 000-3 $000 \mathrm{mg} \mathrm{P} \mathrm{kg}{ }^{-1}$ ) total $\mathrm{P}$ contents, which convert into storage amounts of 8.7-15.2 $\mathrm{t} \mathrm{P} \mathrm{ha}^{-1}$ in 0-50 cm layer. Yet, only $10-20 \%$ of the stored amount is available to plants, $50-60 \%$ is less available and $20-40 \%$ is practically not available to plants (Kuziev 2006).

The soils in the arid region of Khorezm are naturally rich in potassium (K). The total potassium content in the upper horizons ranges from $3000-31000 \mathrm{mg} \mathrm{K} \mathrm{kg}^{-1}$, however, only $10 \%$ of the soils have a total $\mathrm{K}$ of over $2000 \mathrm{mg} \mathrm{kg}^{-1}$. Storage in $0-50 \mathrm{~cm}$ layer varies from 71 to $160 \mathrm{t} \mathrm{K} \mathrm{ha}^{-1}$.

The Khorezm Soil Data Base contains 1869 entries for soil nitrate. The Soviet Union method to determine soil mineral $\mathrm{N}\left(\mathrm{NO}_{3}\right.$ and $\left.\mathrm{NH}_{4}\right)$, is for various reasons (e.g. air-dry soil samples, different chemical analysis) not 1:1 comparable with standard mineral $\mathrm{N}$ determinations in other countries. Therefore, also the classification of $\mathrm{NO}_{3}$ contents with regard to optimal crop growth deviates from European norms (Table 5). 
It appears that the Soviet Union method of chemical analysis of mineral $\mathrm{N}$ gives consistently considerably higher concentrations of $\mathrm{NO}_{3}$ and $\mathrm{NH}_{4}$ than standard "Western" analysis. Hence the following classification was adjusted accordingly.

The $\mathrm{NO}_{3}$ contents in the Khorezm topsoil alone, with on average $34.5 \mathrm{mg} \mathrm{kg}^{-1}$ (median: 19.6), would classify the soil to be medium-rich in mineral $\mathrm{N}$ (Figure 5). The heterogeneity of $\mathrm{NO}_{3}$ contents in $0-30 \mathrm{~cm}$ depth was, however, high as evidenced by the range from a lower quartile of $8.5 \mathrm{mg} \mathrm{kg}^{-1}$ to an upper quartile of $53.7 \mathrm{mg} \mathrm{kg}^{-1}$. Median $\mathrm{NO}_{3}$ content decreases from $12.0 \mathrm{mg} \mathrm{kg}^{-1}$ in $30-56 \mathrm{~cm}$ depth to $6.3 \mathrm{mg} \mathrm{kg}^{-1}$ below 156 $\mathrm{cm}$. Interestingly, $\mathrm{NO}_{3}$ contents below $156 \mathrm{~cm}$ vary more than in the three layers above. This may be an additional indication of topsoil nitrate leaching and accumulation in this sublayer, at least in some soils.

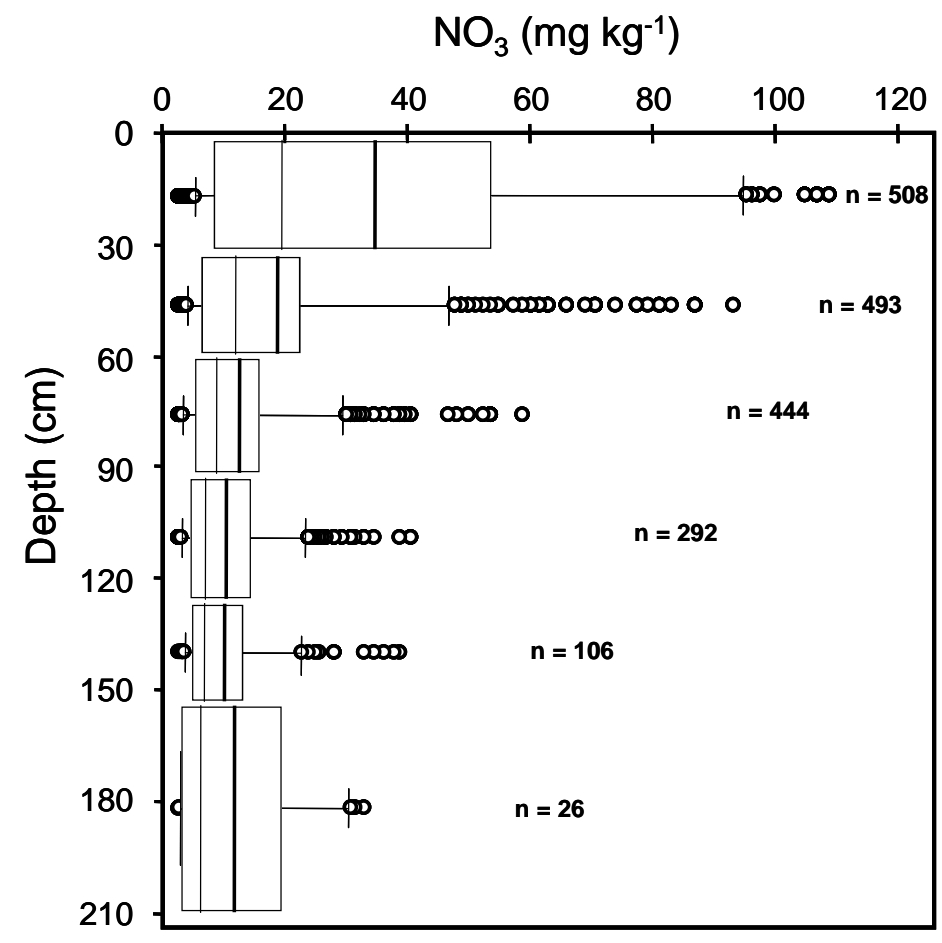

Figure 5: $\mathrm{NO}_{3}$ content of soils in the Khorezm soil database; box-whisker plots, bold lines indicate average values, thin lines indicate median values.

Table 5: Classification of soil mineral $\mathrm{N}$ content with regard to optimal plant growth (WARMAP \& EC-IFAS, 1998) and its equivalent amounts considering exemplarily 0-30 cm soil depth (soil bulk density assumed to equal as $1.5 \mathrm{~g} \mathrm{~cm}^{-3}$ )

\begin{tabular}{lll}
\hline Mineral N content, $\mathrm{mg} \mathrm{kg}^{-1}$ & Classification & Mass equivalent, $\mathrm{kg} \mathrm{N} \mathrm{ha}^{-1} 30 \mathrm{~cm}^{-1}$ \\
\hline$<20$ & very low & $<90$ \\
$20-30$ & Low & $90-135$
\end{tabular}




\section{Soil salinity and $C$ stock}

According to Kuziev (2006), the area of solonchaks had decreased from $10.8 \%$ to $1.6 \%$ between the 1960s and 1990s, due to ameliorative measures and after having been used for farming. Weakly saline or non-saline areas decreased from 74\% in 1960 to $48 \% 1990$. In the same period, moderately saline soils increased from $21 \%$ to $31 \%$, and highly saline soils, from $6 \%$ to $21 \%$.

The Khorezm soil database contains 2053 entries for soil salinity expressed in total dissolved solids percentages (\%TDS). These values were converted into electrical conductivity, $\mathrm{EC}_{\mathrm{e}}$, using the relationship suggested by Abrol et al. (1988): $\mathrm{EC}_{\mathrm{e}}\left(\mathrm{dS} \mathrm{m}^{-1}\right)=$ \%TDS / 0.064. Using this conversion, the findings showed that the median $\mathrm{EC}_{\mathrm{e}}$ decreases from $10.1 \mathrm{dS} \mathrm{m}^{-1}$ in $0-32 \mathrm{~cm}$ to roughly half of this value $\left(4.7 \mathrm{dS} \mathrm{m}^{-1}\right)$ in $32-60 \mathrm{~cm}$ depth. Below $60 \mathrm{~cm}$ depth, the median soil salinity is basically constant at around $3.8 \mathrm{dS} \mathrm{m}^{-1}$. As with $\mathrm{NO}_{3}$, heterogeneity of salinity is high in the topsoil, where $\mathrm{EC}_{\mathrm{e}}$ ranged from a lower quartile of $3.3 \mathrm{dS} \mathrm{m}^{-1}$ to an upper quartile of $25.8 \mathrm{dS} \mathrm{m}^{-1}$ (Figure 6).

According to the classification of soil salinity by Abrol et al. (1988), most subsoils in Khorezm are slightly- to medium-saline, whereas the majority of topsoils above $60 \mathrm{~cm}$ is strongly saline (Figure 7). 


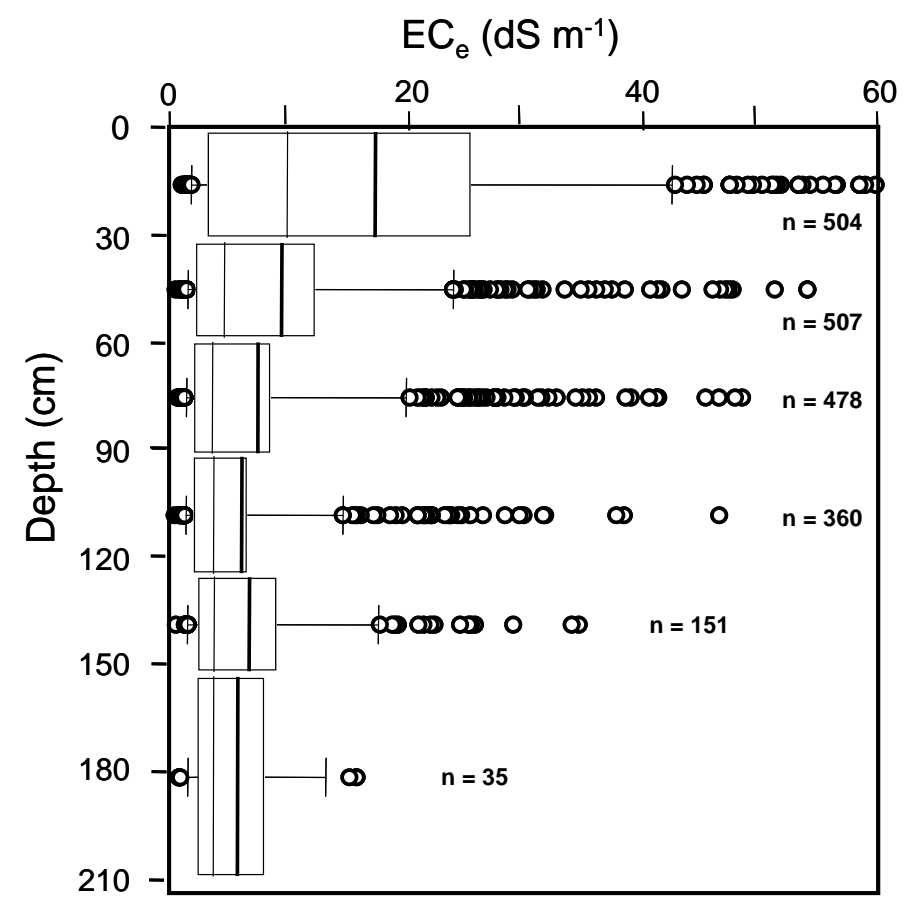

Figure 6: Salinity of soils in the Khorezm soil database; box-whisker plots, bold lines indicate average values, thin lines indicate median values.

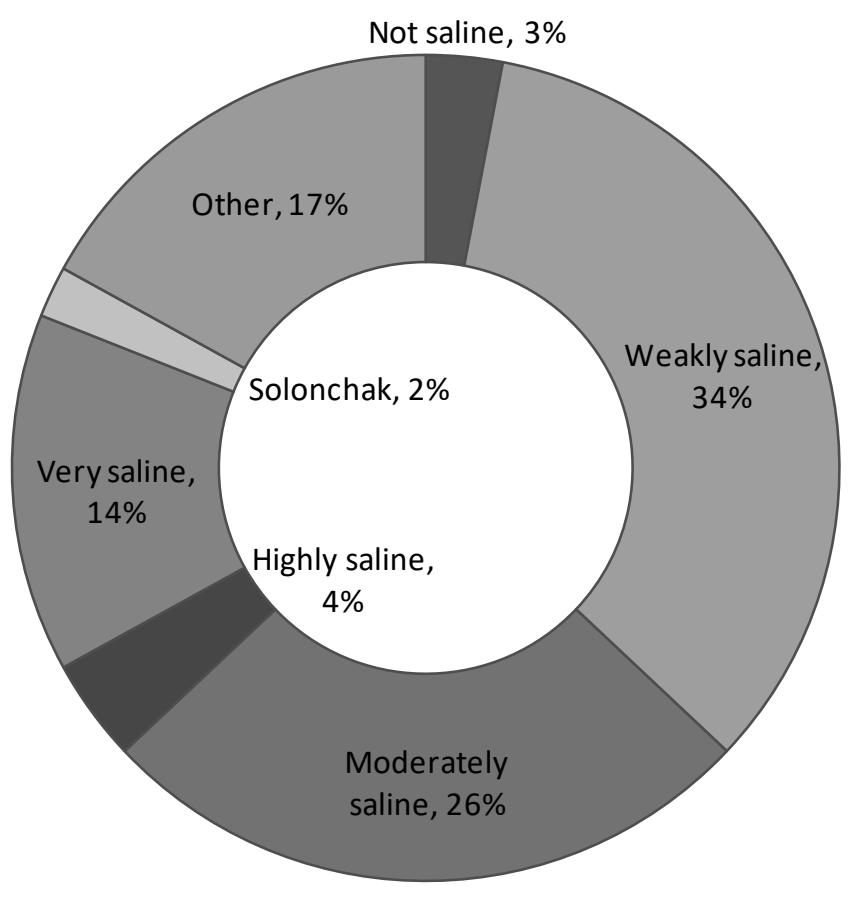

Figure 7: Share of soil salinity classes in the Khorezm region according to the classification by Abrol et al. (1988) 
Land resources in Khorezm can be classified by land use. Agricultural land use covers the largest share of the landscape, compared to natural land use systems such as Tugai forest (the native riparian or floodplain forest, cf. Khamzina et al., this book) and desert. In the following we summarize findings of various studies (Hbirkou et al. 2011, Forkutsa 2006, Massucati 2006) of selected parameters in Tugai forest, desert, tree plantings, shelterbelts between fields, and cotton fields under conventional and conservation agriculture trials referred to as zero tillage on sandy (ZS) and loamy soils (ZL).

The snapshot survey of soil salinity conducted by Hbirkou et al. (2011) suggests that the $\mathrm{EC}_{\mathrm{e}}$ increased in the order Tugai forest $\leq$ desert site $\leq$ long-term afforestation sites < fallow land (Table 6). However, their data also shows that carbon stocks (total carbon $\left(\mathrm{C}_{\mathrm{t}}\right)$ and SOC) were highest on long-term (80 years) afforestation sites, and lowest in the desert ecosystem, suggesting that long-term afforestation had led to an increase of the SOC stock in the topsoil $(0-20 \mathrm{~cm})$ to levels even above those in the native Tugai forest.

Further analysis by Hbirkou et al. (2011) of SOC stocks of fallow land, a 4-years old afforested site, and an 80-years old afforested site suggests a rather rapid initial increase in SOC, which tapers off with time. For instance, fitting all three SOC datasets to a nonlinear regression reveals an increase rate of $0.15 \mathrm{t} \mathrm{SOC} \mathrm{ha-1} \mathrm{a}^{-1}$ after 20 years of afforestation, but a lower increase rate of $0.09 \mathrm{t} \mathrm{SOC} \mathrm{ha}^{-1} \mathrm{a}^{-1}$ after another 60 years of afforestation (Hbirkou et al. 2011).

Table 6: Selected soil ecology parameters of different land use systems in Khorezm region.

\begin{tabular}{|c|c|c|c|c|c|c|c|}
\hline & $\begin{array}{l}{ }^{\mathrm{a}} \mathrm{C}_{\mathrm{tot}}, \\
\mathrm{t} \mathrm{ha}^{-1}\end{array}$ & $\begin{array}{l}{ }^{\mathrm{a} S O C}, \\
\mathrm{t} \mathrm{ha}^{-1}\end{array}$ & $\begin{array}{l}{ }^{\mathrm{a}} \mathrm{EC}_{\mathrm{e}}, \\
\mathrm{dS} \mathrm{m}^{-1}\end{array}$ & $\begin{array}{c}\text { bSoil } \\
\text { fauna } \\
\text { biodiversit } \\
\text { y (Hs') }\end{array}$ & $\begin{array}{c}\text { bSoil fauna } \\
\text { biodiversity } \\
\text { (Hs'Max) }\end{array}$ & $\begin{array}{c}{ }^{\mathrm{c}} \text { Respiration, } \\
\mathrm{mg} \mathrm{CO}_{2} \mathrm{~m}^{-2} \\
\mathrm{~h}^{-1}\end{array}$ & $\begin{array}{c}{ }^{\mathrm{c}} \text { Microbial } \\
\text { biomass, } \mu \mathrm{g} \\
\mathrm{C}_{\text {mic }} \mathrm{g}^{-1} \mathrm{dm}\end{array}$ \\
\hline Tugai & 72.5 & 21.4 & 9.4 & 0.97 & 1.34 & 257.5 & 549.64 \\
\hline Desert & 42.7 & 6.6 & 10.4 & 0.14 & 0.14 & N/A & N/A \\
\hline Tree strip & 92.6 & 29.9 & 13.8 & 0.52 & 0.88 & N/A & N/A \\
\hline $\begin{array}{l}\text { Conventio } \\
\text { nal fields }\end{array}$ & 77.8 & 21.5 & 17.1 & 1.12 & 1.25 & 419.2 & 654.17 \\
\hline NT loam & & & & 0.93 & 1.17 & 376.0 & 1001.04 \\
\hline NT sandy & & & & 0.72 & 0.78 & 241.0 & 216.95 \\
\hline
\end{tabular}

Source: a = Hbirkou et al. (2011); b = Massucati (2006); c = Forkutsa (2006) 


\section{Soil microbiological activity}

Soil microbiological activity (Forkutsa 2006) has a key role in the ecological function of soil (decomposition of organic residues, essential soil nutrients for plants, soil quality) and maintenance of soil fertility. Soil micro-organismic activity depends on the presence of moisture, nutrients and organic matter. Soil respiration is known as a biological indicator for microbial decomposition of organic matter in the soil. Mechanical disturbance causes excessive aeration of soil, while intensity and frequency of disturbance results in a differential distribution and loss of organic matter (Gajri et al. 2002).

The effect of farming practices on soil quality was evaluated at three agricultural sites, which differed in soil management techniques (conventional tillage and zero tillage; with and without mulch), soil texture (loam and sand), and Tugai forest. The carbon dioxide output is consistent with the overall metabolic activity of the soil microflora. Although no pronounced difference between the sites and treatments was found, the respiration rates among the sites decreased in the order: Amir Temur Farm (Loamy) > Khiva Farm Loamy > Tugai forest > Khiva Farm Sandy; i.e. the agriculturally managed loamy soils have a higher microbial activity than the natural Tugai forests and the sandy soils.

Sandy textured soils (Khiva Sandy site) with poor SOC contents (1.7-2.8 $\mathrm{g} \mathrm{kg}^{-1}$ ) had a low range of respiration rates $\left(75.0\right.$ to $\left.390.8 \mathrm{mg} \mathrm{CO}_{2} \mathrm{~m}^{-2} \mathrm{~h}^{-1}\right)$. In contrast, loamy soils with higher SOC (3.8 to $6.2 \mathrm{~g} \mathrm{~kg}^{-1}$ ) showed respiration ranges from 130.83 to $949.2 \mathrm{mg}$ $\mathrm{CO} 2 \mathrm{~m}^{-2} \mathrm{~h}^{-1}$. Spatial differences across the sites were mostly explained by $\mathrm{C} \%$ and soil moisture.

Soil microbial biomass-C $\left(\mathrm{C}_{\mathrm{mic}}\right)$ resulted in similar patterns among all sites. The lowest $\mathrm{C}_{\text {mic }}$ was found at the Khiva Sandy site, in the range of 77.9 to $312.8 \mu \mathrm{g} \mathrm{C} \mathrm{g}^{-1} \mathrm{dm}$, and the highest range at the Khiva Loamy site with 765.5 to $1430.5 \mu \mathrm{g} \mathrm{C} \mathrm{g}^{-1} \mathrm{dm}$. Yet, in spite of the similar soil texture in both Khiva Loamy and Amir Temur sites, the higher $\mathrm{C}_{\text {mic }}$ values (765.49 $\mu \mathrm{g} \mathrm{C}^{-1} \mathrm{dm}$ or higher) in the Khiva Loamy site, where soil conservation techniques were applied (cf. Egamberdiev et al., this book), indicate a better soil quality here than in Amir Temur where only $654.17 \mu \mathrm{g} \mathrm{C} \mathrm{g}^{-1} \mathrm{dm}$ were found.

In this study, the microbial quotient $\left(\mathrm{C}_{\text {mic }} / \mathrm{C}_{\text {org }}\right)$ varied in the range of 2.2-18.2 (\%) (Table 7). Often, this value lies in the range of 1-5\% (Sparling 1997), however some studies conducted in similar environmental conditions on wheat crop fields have shown a similar wide range of soil microbial ratio values (6.2-26.6\%; Insam 1990; Uçkan and Okur 1998). 
Higher values can be interpreted as a carbon accumulation, whilst lower ones stand for carbon loss. Yet, Insam and Öhlinger (1996) stated that the soil microbial quotient is highly influenced by climate and thus, arid areas produce higher values than humid (and less hot) environments. Therefore, the microbial quotients in this study indicate that significant carbon accumulation had occurred on sites under zero-tillage treatment. The metabolic quotient $\left(q \mathrm{CO}_{2}\right)$ (Table 7$)$ is the rate of soil respiration in terms of the microbial biomass and indicates the qualitative influence on microbial biomass. Lower $q \mathrm{CO}_{2}$ ratio values stand for more efficient microbial turnover. Based on microbial and metabolic quotients, our study shows a slight positive effect of zero tillage on soil quality.

Table 7 Soil microbial biomass-C $\left(\mathrm{C}_{\mathrm{mic}}\right)$, soil organic matter $(\mathrm{SOM})$, microbial quotient and metabolic quotient on four sites in different districts of Khorezm (values followed by the same letter are not significantly different; Tukey test, HSD, $\mathrm{P}<0.05$ )

\begin{tabular}{|c|c|c|c|c|c|}
\hline Site & $\begin{array}{l}\text { Treat- } \\
\text { ment }\end{array}$ & $\begin{array}{c}\mathrm{C}_{\text {mic }} \\
\mu \mathrm{g} \mathrm{C}_{\text {mic }} \mathrm{g}^{-1} \mathrm{dm}\end{array}$ & $\begin{array}{c}\text { SOM } \\
\%\end{array}$ & $\begin{array}{c}\text { Microbial } \\
\text { Quotient, } \\
\mathrm{C}_{\text {mic }} / \mathrm{C}_{\text {org }}, \%\end{array}$ & $\begin{array}{c}\text { Metabolic Quotient, } \\
\mathrm{mg} \mathrm{CO}_{2}-\mathrm{C} \mathrm{g}^{-1} \mathrm{Cmic} \mathrm{h}^{-1}\end{array}$ \\
\hline \multirow{4}{*}{$\begin{array}{l}\text { Khiva } \\
\text { Loamy }\end{array}$} & $\mathrm{C}$ & $970.79 \mathrm{~b}$ & $0.87 \mathrm{bc}$ & 13.8 & 1.9 \\
\hline & $\mathrm{C}+$ & $765.49 \mathrm{a}$ & $0.69 \mathrm{bc}$ & 8.7 & 4 \\
\hline & $\mathrm{Z}$ & $1430.48 \mathrm{c}$ & $0.79 \mathrm{bc}$ & 18.2 & 2.4 \\
\hline & $Z_{+}$ & $837.39 \mathrm{ab}$ & $0.79 \mathrm{bc}$ & 10.6 & 3.1 \\
\hline \multirow{4}{*}{$\begin{array}{l}\text { Khiva } \\
\text { Sandy }\end{array}$} & $\mathrm{C}$ & $195.56 \mathrm{ab}$ & $0.37 \mathrm{a}$ & 5.3 & 3.9 \\
\hline & $\mathrm{C}+$ & 77.92 a & $0.35 \mathrm{a}$ & 2.2 & 7.3 \\
\hline & $\mathrm{Z}$ & $312.82 \mathrm{~b}$ & $0.33 \mathrm{a}$ & 9.4 & 3.9 \\
\hline & $\mathrm{Z}+$ & $281.49 \mathrm{~b}$ & $0.43 \mathrm{a}$ & 6.6 & 1.6 \\
\hline $\begin{array}{l}\text { Amir } \\
\text { Temur }\end{array}$ & $\mathrm{C}$ & $654.17 \mathrm{~b}$ & $0.99 \mathrm{c}$ & 6.6 & 8.1 \\
\hline $\begin{array}{l}\text { Tugai } \\
\text { forest }\end{array}$ & $\mathrm{N}$ & $549.64 \mathrm{~b}$ & $0.68 \mathrm{~b}$ & 2.3 & 2.5 \\
\hline
\end{tabular}

Results of site comparisons of the mean difference in soil respiration and SOM were in consistency with studies of Conant et al. (2000) and Huxman et al. (2004), who suggest that soil respiration in semiarid ecosystems is mainly controlled by soil $\mathrm{C}$ content and moisture, which should also apply for arid regions as Khorezm. In the microbiological analysis, similar to the field measurements, the mulching contribution was not captured; possibly due to the short period of residue management in this field prior to the data 
collection, and also due to the chosen sampling depth $(0-20 \mathrm{~cm})$. However, the average values of soil microbial biomass carbon for conventional fields were lower than those for zero-tillage fields, which indicates that an initial, favorable SOM accumulation takes places under zero-tillage practice.

\section{Soil fauna density and diversity}

For the screening of the soil fauna, Massucati (2006) collected macro- and mesofauna using soil cores of $20 \mathrm{~cm}$ diameter and $20 \mathrm{~cm}$ depth. Additionally, litter samples were collected from $80 \mathrm{~cm}$ diameter areas on the forest floor. The soil macro-invertebrates were then extracted in a heat-moisture gradient in a Berlese apparatus.

The density of the soil fauna (macro- and mesofauna) in Khorezm ranged between 29 individuals $\mathrm{m}^{-2}$ in the desert Kyzylkum ${ }^{2}$ and 3994 individuals $\mathrm{m}^{-2}$ in the Tugai forest (Figure 8). The upper level fauna density value in the Tugai forest was caused mainly by the extreme abundance of ants (Hymnoptera: Formicidae), which made up 93\% of the total individuals at this site. The abundance of this taxon is high in arid habitats, where soil fauna assemblages are mostly characterized by xerothermal species (Veile 1992). The soil from the Tugai forest served also as habitat for many larvae of flies (Diptera: Asilidae, Sarcophagidae) and beetles (Coleoptera: Chrysomelidae, Cryptophagidae), and a variety of spiders (Arachnida: Gnaphosidae, Lycosidae, Pseudoscorpionida). In tree strips $^{3}$ around cotton field the density was 1344 individuals $\mathrm{m}^{-2}$, mainly characterized by Formicidae. Both tree strips and forest offer better habitats for social insects such as fire ants (Myrmicinae; Solenopsis sp), to build epigeic nests, since these areas are not used for agriculture. Termites are often found in the desert zones (Abdullaev et al. 2002) but they also affect buildings, often historical ones, e.g. in the ancient city of Khiva, an UNESCO heritage site.

\footnotetext{
${ }^{2}$ fixed and mobile dunes with open, psammophytic, shrub-like communities and semi-shrub, succulent plants, as well as tessellated takyr soils with a thin loam crust without vegetation.

${ }^{3}$ planted trees (predominantly Populus ariana and Elaeagnus angustifolia) within a cotton field, for wind erosion protection
} 


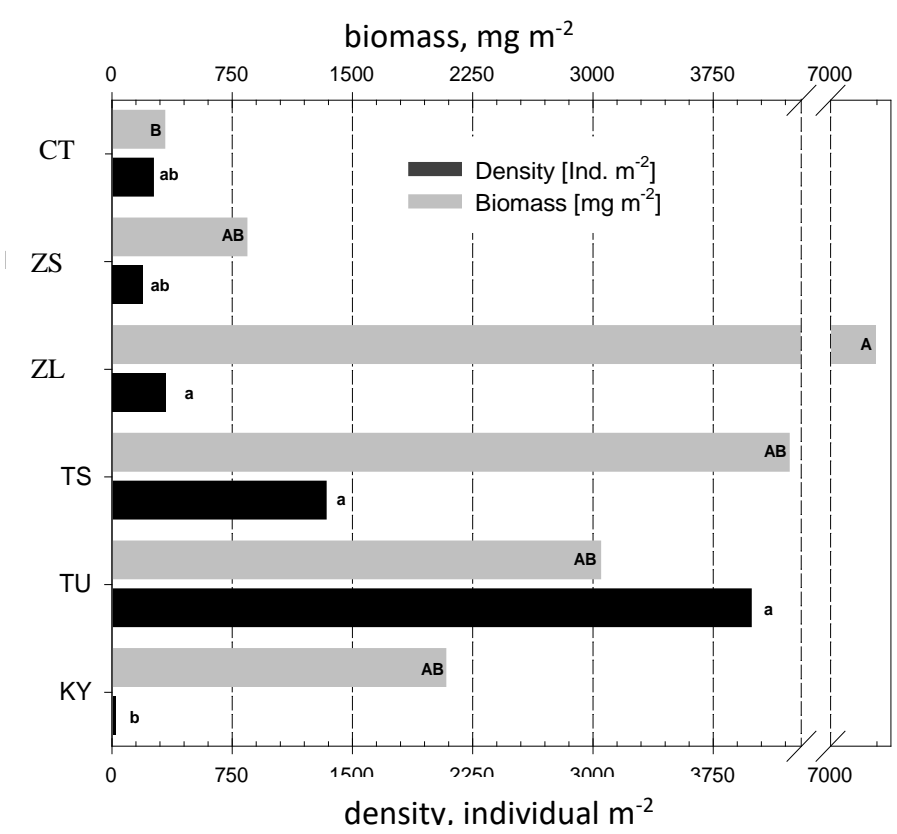

Figure 8. Mean density (individual $\mathrm{m}^{-2}$ ) and biomass (fresh weight; $\mathrm{mg} \mathrm{m}^{-2}$ ) of the soil fauna at different study sites in Khorezm (CT: conventional tillage; ZS: zero-tillage (sand soil); ZL: zero-tillage (loamy soil); TS: tree strips; TU: Tugai forest; KY: Kyzylkum desert). Sample sites followed by the same letter are not significantly different (ANOVA, Scheffé, $. \alpha=0.05)$

The soil fauna density under conventional tillage was 267 individuals $\mathrm{m}^{-2}$, showing no significant difference from the density in the Tugai forest, tree strips and in zero tillage fields. Analogous to the forest site and tree strips, ants were also the most important component of the soil fauna assemblage at this study site. This may primarily be explained by the favorable environmental conditions of adjacent tree strips, where social insects find refuge to build long-lasting nests. Secondly, ants have a wide diet spectrum (Martius et al. 2001), enabling them to colonize many different systems.

Under zero-tillage in the ZS and ZL sites (zero-tillage on sandy and loamy soil, respectively; cf. Figure 8), isopods (woodlice; Isopoda: Oniscidea) were the most dominant taxon, accounting for $41 \%$ of the total soil fauna. Isopods (and myriapods) belong to a suitable indicator group for soil disturbance, since they are sensitive to soil tillage, and as a consequence are rare in cultivated soils (Paoletti 1999, Holland 2004). This group, which was observed across the tree strips too, enhances nutrient cycling by decomposing organic detritus and transporting it to moister microsites in the soil. Other two important taxa for soil structure and formation were observed under zero-tillage, earthworms (Oligochaeta; Lumbricidae) and myriapods (Diplopoda; millipedes). 
Earthworm and myriapod assemblages can positively be affected by conservation agriculture as observed in previous studies (e.g. Chan 2001, Holland 2004). For isopods and myriapods in particular, the retention of surface mulch modifies the physical soil properties (e.g. prevention of water evaporation), increasing the architectural complexity of the soil surface environment, and as consequence facilitating their movements (Holland 2004). However, the residues left on the soil surface did not affect the population of generalist predators, such as ground beetles and spiders, as previously concluded (e.g. Szendrei and Weber 2009). Thus, both conservation agriculture and tree strips may improve the environmental sustainability of irrigated arable lands in Khorezm, by offering refuge, shelter over the irrigation and cultivation season, overwintering grounds, and food reservoirs, especially in springtime, for many soil taxa.

Biodiversity, calculated by the Shannon-Wiener-Index, was the highest (1.3) under conventional tillage (CT), although it was not significantly different from Tugai and zerotillage fields. The high diversity of invertebrates seems to be linked to the very specific soil fauna community under cultivated soils.

\section{Soil fauna biomass}

The soil fauna biomass, in contrast with soil fauna density, was the highest under conservation agriculture on the loamy soil (ZL) with $7099 \mathrm{mg} \mathrm{m}^{-2}$ (all data in fresh mass) and the lowest under conventional tillage (CT) with $337 \mathrm{mg} \mathrm{m}^{-2}$. In natural Tugai stands, biomass was in between, with $3055 \mathrm{mg} \mathrm{m}^{-2}$. Surprisingly, the biomass of the soil fauna in tree strips and even in the desert was higher than under conventional tillage fields (4 231 and $2090 \mathrm{mg} \mathrm{m}^{-2}$, respectively). Mole crickets (Ensifera; Grylotalpa) accounted for 49 and $94 \%$ of the total biomass in the tree strips and desert, respectively.

Soil fauna biomass was expected to be low in these very dry, hot, winter-cold regions, and the observed values (if divided by 3 to provide for a crude fresh-to-dry mass recalculation; Martius unpublished) are actually less than half those at the lower end of the biomass range in healthy, natural, temperate middle-European beech forests (which have a soil fauna dry mass of 5-15 $\mathrm{g} \mathrm{m}^{-2}$; Schaefer and Schauermann 1990) or in Amazonian tropical primary rainforests (approx. $3 \mathrm{~g} \mathrm{~m}^{-2}$ dry mass; Höfer et al. 2001). However, conservation agriculture was able to elevate the soil fauna biomass levels above those in the natural Tugai forests stands; in spite of the widespread soil salinization and widespread (past) pesticide application, but consistent with the higher moisture levels in the irrigated croplands. Under zero-tillage, the biomass of earthworms (Oligochaeta; 
Lumbricidae) accounted for $79 \%$ of the total biomass at this study site. Earthworms are widely known as ecosystem engineers, providing a wide variety of ecosystem services linked to soil formation and retention of organic matter.

Under conventional tillage, the lower biomass combined with a high number of individuals showed that the soil fauna assemblage at this study site is densely populated by small-sized taxa. This result is consistent with the idea that the anthropogenic condition influences the soil fauna community. The invertebrates under CT were on average smaller, but they are resilient to cultivated/irrigated soils. According to Kladivko (2001), larger species are more vulnerable to soil cultivation than smaller ones, due to the physical disruption, changes in soil environment conditions, and the burial of crop residues. The soil fauna community under CT was characterized by polyphagous prepadors, which comprised carabid (Coleptera: Carabidae; Bembidiinae) and rove beetles (Coleptera: Staphylylinidae; Platystethus sp.), ants (Formicidae: Aphanogaster sp.), and sheet web spiders (Linyphiidae). This fauna assemblage is expected to play a large role in regulating insect populations in this agrocenosis, which might contribute to the ecological services (i.e. pest control) of conservation agriculture. This finding is supported by previous studies showing a preference of carabid and rove beetles for cultivated fields (Paoletti 1999, Holland 2004) and a possible adaptation of sheet web spiders to arable fields (Krause 1987).

\section{Summary and conclusions}

The upper horizons of the soils in Khorezm are new formations due to the combined effects of river flow dynamics and the introduced irrigation systems, when compared to soils developed under natural conditions, i.e. without human interference. More than $95 \%$ of the irrigated area consists of meadow soils; about $4 \%$ are marshy-meadow soils. Meadow soils, developed on alluvial deposits, are considered to be the best land resources and most of these soils have already been cultivated. Soils developed on illuvium are less suitable for farming with only a fraction of these soils currently being cultivated.

Most soils in Khorezm are silt loams, sandy loams, and loams (USDA soil texture classification) which constitute $80 \%$ of all soil layers. Heavier, clayey soils are largely absent in Khorezm. Since the texture of the top soil profiles turned out to be rather homogenous in the top $56 \mathrm{~cm}$ and even the top $\sim 129 \mathrm{~cm}$, it allows a robust estimation of vertical distribution of soil texture based only on topsoil data. This in turn allows 
estimating clay content and other highly correlated parameters, for example soil moisture holding capacity on large spatial scales for modeling purposes.

For this kind of dryland region with inherent low SOM and very little soil organisms, conservation agriculture seem to improve soil health (SOM) rapidly. The faunistic studies revealed the highest density of the soil macro- and mesofauna in the native riparian forest Tugai, mainly represented by ant assemblages (93\%), compared with the habitats under agricultural use. In contrast, earthworm populations greatly contribute to biomass increase under conservation agriculture. The soil fauna biodiversity was greater under conventional tillage, but the assemblage here was mostly characterized by small predatory arthropods, pointing at disturbances from the tillage.

Summing up, the soils in Khorezm are mostly former illuvial and dryland soils heavily influenced by human interference; in some cases (soil near old settlements and those closer to the river) possible over millennia, but mostly as a result of the expansion of irrigated agriculture over roughly the last 80-100 years. Soil organic matter levels are typically low. The disturbances, drought, possibly the salinity and the usual high temperatures reduce soil biological processes to a high degree; but irrigated soils offer a certain degree of improvements in the living conditions of soil organisms for providing more steady moisture levels over the year. Soil life can be restored by conservation agriculture to a certain extent, which is consistent with findings on soil organic matter by Egamberdiev et al. (this book). Whether the resulting ecosystem services are of any importance for management purposes cannot be said at the present stage, but the large amount of predator feeding guilds in the soil fauna suggests that a certain contribution to crop pest control can be expected from those groups, which might be welcome under the currently often high pest incidence levels in cotton and wheat (Khamraev and Davenport 2004) (and possibly, it could be enhanced through adequate soil management). The study also indicates that earthworm monitoring might be a good way to assess improvements in soil biology, as earthworms represent a keystone species under the decomposers; their populations increase greatly under conservation agriculture, and they are easily monitored.

Most subsoils in Khorezm are slightly- to medium-saline, whereas the majority of topsoils above $60 \mathrm{~cm}$ are strongly saline. Areas covered by forests and deserts tend to have lower salinity levels. Due to poor soil organic matter (SOM) content, total nitrogen (N) levels are also low, this requires application of significant amounts of mineral 
fertilizers in order to grow crops, including nutrient intensive crop such as cotton. Despite the soils in the arid region of Khorezm being rich in potassium, to sustain and improve overall soil fertility there is a need for the balanced use of available resources and to avoid nutrient mining. Management options such as conservation agriculture and afforestation seem to bring fast benefits to these soils often impoverished by irrigation and land use and can to a certain extent mitigate (but not revert) soil salinity, currently the most limiting factor for agricultural productivity.

\section{References}

Abdullaev, I.I., Khamraev, A.S., Martius, C., Nurjanov, A.A., Eshchanov, R.A. 2002. Termites (Isoptera) in irrigated and arid landscapes of Central Asia (Uzbekistan). Sociobiology. Vol. 40 (3), 605-614.

Abrol, I.P., Yadav, J.S.P., Massoud, F.I. 1988. Salt-affected soils and their management. FAO Soils Bulletin 39. FAO, Rome, 131 p.

\section{Bobojonov et al., this book}

Brouwer, C., Goffeau, A., Heibloem, M. 1985. Introduction to irrigation. Irrigation Water Management Training Manual, No. 1. Food and Agricultural Organization of the United Nations, Rome.

Chan, K.Y. 2001. An overview of some tillage impacts on earthworm population abundance and diversity - implications for functioning in soils. Soil and Tillage Research, 57, 179-191.

Conant, R.T., Klopatek, J.M. and Klopatek, C.C. 2000. Environmental factors controlling soil respiration in three semiarid ecosystems. Soil Science Society American Journal 64:383-390.

Egamberdiev, O., Kienzler, S., Sayre, K., Tursunov, L., Pulatov, A. Lamers, J. P. A., Martius, C. Introducing conservation agriculture on irrigated meadow alluvial soils (Arenosols) in Khorezm, Uzbekistan. In: Martius, C., I. Rudenko, JP.A. Lamers, P.L.G. Vlek (2011): Cotton, water, salts and Soums - economic and ecological restructuring in Khorezm, Uzbekistan. Springer, Berlin, Heidelberg, New York.

Felitciant, I. N. 1964. Soils of Khorezm province. In: Soils of Uzbekistan SSR. Volume III. Tashkent, Uzbekistan, p. 133-211. (in Russian) 
Forkutsa, O. 2006. Assessing soil-borne $\mathrm{CO}_{2}$ exchange in irrigated cropland of the Aral Sea Basin as affected by soil types and agricultural management. MA Thesis, University of Bonn, ARTS programme. 73 pp.

Gajri P.R., V.K. Arora and S.S. Prihar. 2002. Tillage for sustainable cropping. Food Products Press, New York.

GKZGK 2009. National report on land resources of Uzbekistan. State Committee on Land Resources, Geodesy, Cartography and Cadastre. 95pp. (in Uzbek) http://www.gkz.uz/files/any/2009.pdf

Hbirkou, C., C. Martius, A. Khamzina, J.P.A. Lamers, G. Welp, W. Amelung. 2011. Reducing topsoil salinity and raising carbon stocks through afforestation in Khorezm, Uzbekistan. Journal of Arid Environments, 75, 146-155.

Höfer, H., Hanagarth, W., Beck, L., Garcia, M., Martius, C., Franklin, E., Römbke, J. (2001): Structure and function of the soil fauna in Amazonian anthropogenic and natural ecosystems. Eur. J. Soil Biol. 37, 229-235

Holland, J. M. 2004. The environmental consequences of adopting conservation tillage in Europe: reviewing the evidence. Agriculture, Ecosystems and Environment, 103, 125 .

Huxman, T.E., Snyder, K.A., Tissue, D., Leffler, A.J., Ogle, K., Pockman, W.T., Sanquist, D.R., Potts, D.L. and Schwining, S. 2004. Precipitation pulses and carbon fluxes in semiarid and aird ecosystems. Oecologia 141:254-268.

Ibrakhimov, M., Khamzina, A., Forkutsa, I., Paluasheva, G., Lamers, J.P.A., Tischbein, B., Vlek, P.L.G., Martius, C. 2007. Groundwater table and salinity: Spatial and temporal distribution and influence on soil salinization in Khorezm region (Uzbekistan, Aral Sea Basin). Irrig. Drainage Syst., 21 (3-4), 219-236.

Insam, H. 1990. Are the microbial biomass and basal respiration governed by the climatic regime? Soil Biol. Biochem. 22:525-532.

Insam, H. and Öhlinger, R. 1996. Ecophysiological parameters, In: F. Schinner, et al. Methods in Soil Biology. Springer-Verlag. pp. 1-426.

Khamraev, A. Sh. and Davenport, C. F. 2004. Identification and control of agricultural plant pests and diseases in Khorezm and the Republic of Karakalpakstan, Uzbekistan. 124 pp. ZEF Work Papers for Sustainable Development in Central Asia, 8. Available 
at:

http://www.khorezm.zef.de/fileadmin/webfiles/downloads/projects/khorezm/downloa ds/Publications/wps/ZEF-UZ-WP08-Khamraev-Davenport.pdf

\section{Khamzina et al. this book}

Kladivko, E.J. 2001. Tillage systems and soil ecology. Soil and Tillage Research, 61, 6176.

Krause, A. 1987. Untersuchungen zur Rolle von Spinnen in Agrarbiotopen. PhD Thesis. Rheinischen Friedrich-Wilhelms-Universität Bonn, Germany, 284. (in German)

Kuziev, R. 2006. Soil evolution in Khorezm region. Unpublished Report, Urgench. 47p. (in Russian)

Martius, C., Römbke, J., Verhaagh, M., Höfer, H. and Beck, L. 2001. Termiten, Regenwürmer und Ameisen- prägende Elemente der Bodenfauna tropischer Regenwälder. Karlsruhe, Staatliches Museum für Naturkunde Karlsruhe. Adrias, 15, $15-27$.

Massucati, L. 2006. Monitoring of soil macrofauna and soil moisture in a cotton field: an assessment of the ecological potential in irrigated agriculture in Central Asia (Khorezm Province, Uzbekistan). Diploma Thesis. University of Bonn, 104 pp.

Nelson, D.W., Sommers, L.E. 1982. Total carbon, organic carbon and organic matter. In: Methods of soil analysis, Page, A.L.; Miller, R.H.; Keeney, D.R., (Eds.), American Soc. of Agronomy, Madison, Wisconsin, USA. 539-549.

Paoletti, G. M. 1999. Using bioindicators based on biodiversity to assess landscape sustainability. Agriculture, Ecosystem and Environment, 74, 1-18.

Schaefer, M., Schauermann, J. 1990. The soil fauna of beech forests: comparison between a mull and a moder soil. Pedobiologia 34(5), 299-314.

Shein, E. V. 2009. The particle-size distribution in soils: Problems of the methods of study, interpretation of the results, and classification. Eurasian Soil Science, 42, 284291.

Sommer, R., Djanibekov, N. and Salaev, O. 2010. Optimization of land and resource use at farm-aggregated level in the Aral Sea Basin of Uzbekistan with the integrated model FLEOM - model description and first application, ZEF- Discussion Papers On 
Development Policy No. 139, Center for Development Research, Bonn, July 2010, pp.102. http://papers.ssrn.com/sol3/papers.cfm?abstract_id=1650631

Sparling, G.P. 1997. Soil microbial biomass, activity and nutrient cycling as indicators of soil health, In: C.E. Pankhurst, et al. Biological indicators of soil health. CAB International, New York. pp. 97-119.

Stolbovoi, V. 2000. Soils of Russia: Correlated with the revised legend of the FAO soil map of the world and world reference base for soil resources. Research Reports. IIASA, Vienna.

Szendrei, Z., Weber, D.C. 2009. Response of predators to habitat manipulation in potato fields. Biological Control, 50, 123-128.

Tashkuziev, M.M. 2003. Soils of Khorezm province. Tashkent, p. 69-91 (in Uzbek).

\section{Tischbein et al. this book}

Tolstov, S. P. 1948. Following the tracks of Khorezmian civilization. Popular-scientific series. Published by the Academy of Sciences of the USSR, Moscow - Leningrad.

Tsvetsinskaya, E.A., Vainberg, B.I., Glushko, E.V. 2002. An integrated assessment of landscape evolution, long-term climate variability, and land use in the Amudarya Prisarykamysh delta. Journal of Arid Environments 51: 363-381.

Tursunov, L. 1981. Soil conditions of irrigated lands of the western parts of Uzbekistan. Tashkent. 222 pp. (in Russian)

Uckan, H.S. and Okur, N. 1998. Seasonal changes in soil microbial biomass and enzyme activity in arable and grassland soils [Online]. Available by Türkie Toprak Ilmi Derengi http://www.toprak.org.tr/isd/isd_77.htm.

Veile, D. 1992. Ameisen-Grundzüge der Erfassung und Bewertung. In: J. Trauter [ed]. Artenund Biotopschutz in der Planung: Methodische Standards zur Erfassung von Tierartengruppen [BVDL- Tagung Bad Wurzach, 9. 10. November1991]. Weikersheim, Josef Margraf Verlag, Ökologie In Forschung Und Anwendung, 5, pp. 177-188.

Vorobyova, L.A. 1998. Khimicheskiy analiz pochv (Chemical analysis of soils). Moscow University Press, Moscow, 272 pp, (in Russian).

WARMAP and EC-IFAS 1998. Water Use and Farm Management Survey (WUFMAS) Agricultural Year 1998 - Annual Report. Water Resources Management and 
Agricultural Production in the Central Asian Republics (WARMAP-2); Executive Committee Interstate Fund for the Aral Sea (EC-IFAS); TACIS Project. 